Article

\title{
The Solubility Parameters of Ionic Liquids
}

\author{
Andrzej Marciniak \\ Department of Physical Chemistry, Faculty of Chemistry, Warsaw University of Technology, \\ Noakowskiego 3, 00-664 Warsaw, Poland; E-Mail: a.marciniak@ch.pw.edu.pl; \\ Tel.: +48-222-345-816; Fax: +48-226-282-741
}

Received: 1 March 2010; in revised form: 21 April 2010 / Accepted: 22 April 2010 /

Published: 27 April 2010

\begin{abstract}
The Hildebrand's solubility parameters have been calculated for 18 ionic liquids from the inverse gas chromatography measurements of the activity coefficients at infinite dilution. Retention data were used for the calculation. The solubility parameters are helpful for the prediction of the solubility in the binary solvent mixtures. From the solubility parameters, the standard enthalpies of vaporization of ionic liquids were estimated.
\end{abstract}

Keywords: ionic liquid; Hildebrand's solubility parameter; standard enthalpy of vaporization

\section{Introduction}

Ionic liquids (ILs) have become the subject of an increasing number of investigations due to their unique properties such as wide liquid range, stability at high temperatures, no flammability and negligible vapor pressure. Ionic liquids as green solvents can be used in separation processes, synthesis, catalysis and electrochemistry, successfully replacing the conventional volatile, flammable and toxic organic solvents. Since the ILs have a negligible vapor pressure, the inverse gas chromatography (IGC) is a suitable method for measuring thermodynamic properties of pure substances and their mixtures [1]. From the retention data, the activity coefficients at infinite dilution, Flory-Huggins interaction parameters as well as the Hildebrand's solubility parameters can be determined. Activity coefficients at infinite dilution are very important for calculations of selectivity and capacity of entrainers for the different separation problems, characterizing the behavior of liquid mixtures, estimation of mutual solubilities, fitting the excess molar energy $\left(G^{\mathrm{E}}\right)$ model parameters (e.g., Wilson, NRTL, UNIQUAC), predicting the existence of an azeotrope, analytical 
chromatography, calculation of Henry constant and partition coefficients, development of thermodynamic models based on the group contribution methods such as mod. UNIFAC [2]. The values of the activity coefficients at infinite dilution for the investigated ionic liquids were published earlier [3-18].

The Hildebrand's solubility parameters have numerous applications including gas-liquid solubility, solvent extraction and many others as described in detail in the literature [19,20].Solubility parameters are available for only some of the ionic liquids determined by IGC [21-24], intrinsic viscosity method [25] or estimated from Kamlet-Taft equation [26]. This paper provides information on the Hildebrand's solubility parameters determined for 18 ionic liquids as a function of temperature and the standard enthalpies of vaporization calculated from the values of the solubility parameters.

\section{Results and Discussion}

The Hildebrand's solubility parameters $\left(\delta_{2}\right)$ were calculated for the ionic liquids presented (with abbreviations and structures) in Table 1 . The solubility parameters show a slight dependence on the temperature, which was also observed by Mutelet et al. [21-23]. The results are presented in Table 2 and are compared to results taken from the literature [21-26].

Table 1. Abbreviations, names and structures of investigated ionic liquids.

\begin{tabular}{lll}
\hline \multicolumn{1}{c}{ Abbreviation } & \multicolumn{1}{c}{ Name } & $\begin{array}{l}\text { 1-Ethyl-3-methyl- } \\
\text { imidazolium trifluoroacetate }\end{array}$ \\
\hline$[\mathrm{emim}][\mathrm{TFA}]$ & $\begin{array}{l}\text { 1-Ethyl-3-methyl- } \\
\text { imidazolium thiocyanate }\end{array}$ & $\begin{array}{l}\text { 1-Butyl-3-methyl- } \\
\text { imidazolium thiocyanate }\end{array}$ \\
\hline$[\mathrm{emim}][\mathrm{SCN}]$ & $\begin{array}{l}\text { 1-Hexyl-3-methyl- } \\
\text { imidazolium thiocyanate }\end{array}$ \\
\hline$[\mathrm{bmim}][\mathrm{SCN}]$ & $\begin{array}{l}\text { 1-Butyl-4-methyl- } \\
\text { pyridinium thiocyanate }\end{array}$ \\
\hline$[\mathrm{hmim}][\mathrm{SCN}]$ & $\begin{array}{l}\text { 1-Butyl-1-methyl- } \\
\text { pyrrolidinium thiocyanate }\end{array}$ \\
\hline$[\mathrm{bmPYR}][\mathrm{SCN}]$ & [6]
\end{tabular}


Table 1. Cont.

\begin{tabular}{|c|c|c|c|}
\hline Abbreviation & Name & Structure & Reference \\
\hline$[\mathrm{bmim}]\left[\mathrm{CF}_{3} \mathrm{SO}_{3}\right]$ & $\begin{array}{l}\text { 1-Butyl-3-methyl- } \\
\text { imidazolium } \\
\text { trifluoromethanesulfonate }\end{array}$ & & [8] \\
\hline$[1,3 \mathrm{bmPY}]\left[\mathrm{CF}_{3} \mathrm{SO}_{3}\right]$ & $\begin{array}{l}\text { 1-Butyl-3-methyl- } \\
\text { pyridinium } \\
\text { trifluoromethanesulfonate }\end{array}$ & & [9] \\
\hline$[\mathrm{bmPYR}]\left[\mathrm{CF}_{3} \mathrm{SO}_{3}\right]$ & $\begin{array}{l}\text { 1-Butyl-1-methyl- } \\
\text { pyrrolidinium } \\
\text { trifluoromethanesulfonate }\end{array}$ & & {$[10]$} \\
\hline$[\mathrm{bmim}]\left[\mathrm{MDEGSO}_{4}\right]$ & $\begin{array}{l}\text { 1-Butyl-3-methyl- } \\
\text { imidazolium } \\
\text { 2-(2-methoxyethoxy)ethyl } \\
\text { sulfate }\end{array}$ & & [11] \\
\hline$[\mathrm{bmim}]\left[\mathrm{OcSO}_{4}\right]$ & $\begin{array}{l}\text { 1-Butyl-3-methyl- } \\
\text { imidazolium octyl sulfate }\end{array}$ & & {$[12]$} \\
\hline$\left[\mathrm{P}_{1, \mathrm{i} 4, \mathrm{i} 4, \mathrm{i} 4}\right][\mathrm{TOS}]$ & $\begin{array}{l}\text { Triisobutyl-methyl- } \\
\text { phosphonium tosylate }\end{array}$ & & [13] \\
\hline$[1,4 \mathrm{bmPY}][\mathrm{TOS}]$ & $\begin{array}{l}\text { 1-Butyl-4-methyl- } \\
\text { pyridinium tosylate }\end{array}$ & & {$[14]$} \\
\hline
\end{tabular}


Table 1. Cont.

\begin{tabular}{|c|c|c|c|}
\hline Abbreviation & Name & Structure & Reference \\
\hline$[1,4 \mathrm{bmPY}]\left[\mathrm{NTf}_{2}\right]$ & $\begin{array}{l}\text { 1-Butyl-4-methyl- } \\
\text { pyridinium } \\
\text { bis(trifluoromethylsulfonyl) } \\
\text {-amide }\end{array}$ & & {$[15]$} \\
\hline$\left[\mathrm{C}_{6} \mathrm{OCmim}\right]\left[\mathrm{NTf}_{2}\right]$ & $\begin{array}{l}\text { 1-Hexyloxymethyl-3- } \\
\text { methyl-imidazolium } \\
\text { bis(trifluoromethylsulfonyl) } \\
\text {-amide }\end{array}$ & & {$[16]$} \\
\hline$\left[\left(\mathrm{C}_{6} \mathrm{OC}\right)_{2} \mathrm{im}\right]\left[\mathrm{NTf}_{2}\right]$ & $\begin{array}{l}\text { 1,3-Dihexyloxymethyl- } \\
\text { imidazolium } \\
\text { bis(trifluoromethylsulfonyl) } \\
\text {-amide }\end{array}$ & & {$[16]$} \\
\hline$\left[\mathrm{Et}_{3} \mathrm{~S}\right]\left[\mathrm{NTf}_{2}\right]$ & $\begin{array}{l}\text { Triethyl-sulfonium } \\
\text { bis(trifluoromethylsulfonyl) } \\
\text {-amide }\end{array}$ & & [17] \\
\hline$[\mathrm{hmim}]\left[\mathrm{NTf}_{2}\right]$ & $\begin{array}{l}\text { 1-Hexyl-3-methyl- } \\
\text { imidazolium } \\
\text { bis(trifluoromethylsulfonyl) } \\
\text {-amide }\end{array}$ & & {$[18]$} \\
\hline
\end{tabular}


Table 2. Hildebrand's solubility parameters $\delta_{2}$ for the different ionic liquids.

\begin{tabular}{|c|c|c|}
\hline Ionic liquid & $T / \mathbf{K}$ & $\delta_{2} / \mathrm{MPa}^{0.5}$ \\
\hline \multirow[t]{5}{*}[\mathrm{emim}]{$[\mathrm{TFA}]$} & 298.15 & $25.56^{1}$ \\
\hline & 328.15 & 25.58 \\
\hline & 338.15 & 25.59 \\
\hline & 348.15 & 25.60 \\
\hline & 358.15 & 25.60 \\
\hline \multirow[t]{7}{*}[\mathrm{emim}]{$[\mathrm{SCN}]$} & 298.15 & $25.19^{1}$ \\
\hline & 308.15 & 25.24 \\
\hline & 318.15 & 25.33 \\
\hline & 328.15 & 25.41 \\
\hline & 338.15 & 25.46 \\
\hline & 348.15 & 25.55 \\
\hline & 358.15 & 25.57 \\
\hline \multirow[t]{6}{*}[\mathrm{bmim}]{$[\mathrm{SCN}]$} & 298.15 & $24.64^{1}$ \\
\hline & 318.15 & 24.70 \\
\hline & 328.15 & 24.72 \\
\hline & 338.15 & 24.75 \\
\hline & 348.15 & 24.77 \\
\hline & 358.15 & 24.80 \\
\hline \multirow[t]{7}{*}[\mathrm{hmim}]{$[\mathrm{SCN}]$} & 298.15 & $23.65^{1}$ \\
\hline & 318.15 & 23.74 \\
\hline & 328.15 & 23.79 \\
\hline & 338.15 & 23.84 \\
\hline & 348.15 & 23.90 \\
\hline & 358.15 & 23.93 \\
\hline & 368.15 & 23.98 \\
\hline \multirow[t]{7}{*}[1,4\mathrm{bmPY}]{$[\mathrm{SCN}]$} & 298.15 & 24.53 \\
\hline & 308.15 & 24.57 \\
\hline & 318.15 & 24.62 \\
\hline & 328.15 & 24.67 \\
\hline & 338.15 & 24.71 \\
\hline & 348.15 & 24.74 \\
\hline & 358.15 & 24.77 \\
\hline \multirow[t]{7}{*}{ [bmPYR][SCN] } & 298.15 & 24.96 \\
\hline & 308.15 & 24.98 \\
\hline & 318.15 & 25.00 \\
\hline & 328.15 & 25.01 \\
\hline & 338.15 & 25.02 \\
\hline & 348.15 & 25.04 \\
\hline & 358.15 & 25.05 \\
\hline
\end{tabular}


Table 2. Cont.

\begin{tabular}{|c|c|c|}
\hline Ionic liquid & $T / \mathbf{K}$ & $\delta_{2} / \mathbf{M P a}^{0.5}$ \\
\hline \multirow[t]{7}{*}{ [bmPYR][SCN] } & 298.15 & 24.96 \\
\hline & 308.15 & 24.98 \\
\hline & 318.15 & 25.00 \\
\hline & 328.15 & 25.01 \\
\hline & 338.15 & 25.02 \\
\hline & 348.15 & 25.04 \\
\hline & 358.15 & 25.05 \\
\hline \multirow[t]{7}{*}[\mathrm{bmim}]{$\left[\mathrm{CF}_{3} \mathrm{SO}_{3}\right]$} & 298.15 & $22.67^{1}$ \\
\hline & 308.15 & 22.74 \\
\hline & 318.15 & 22.81 \\
\hline & 328.15 & 22.87 \\
\hline & 338.15 & 22.97 \\
\hline & 348.15 & 23.03 \\
\hline & 358.15 & 23.09 \\
\hline \multirow[t]{6}{*}[1,3\mathrm{bmPY}]{$\left[\mathrm{CF}_{3} \mathrm{SO}_{3}\right]$} & 298.15 & $22.47^{1}$ \\
\hline & 318.15 & 22.61 \\
\hline & 328.15 & 22.68 \\
\hline & 338.15 & 22.75 \\
\hline & 348.15 & 22.84 \\
\hline & 358.15 & 22.89 \\
\hline \multirow[t]{7}{*}[\mathrm{bmPYR}]{$\left[\mathrm{CF}_{3} \mathrm{SO}_{3}\right]$} & 298.15 & $22.83^{1}$ \\
\hline & 318.15 & 22.94 \\
\hline & 328.15 & 23.01 \\
\hline & 338.15 & 23.06 \\
\hline & 348.15 & 23.13 \\
\hline & 358.15 & 23.17 \\
\hline & 368.15 & 23.24 \\
\hline \multirow[t]{3}{*}[\mathrm{bmim}]{$\left[\mathrm{MDEGSO}_{4}\right]$} & 298.15 & 24.80 \\
\hline & 303.15 & 24.80 \\
\hline & 308.15 & 24.81 \\
\hline \multirow[t]{3}{*}[\mathrm{bmim}]{$\left[\mathrm{OcSO}_{4}\right]$} & 298.15 & 22.83 \\
\hline & 313.15 & 23.00 \\
\hline & 328.15 & 23.25 \\
\hline \multirow[t]{6}{*}[\mathrm{P}_{1,\mathrm{i}4,\mathrm{i}4,\mathrm{i}4}]{$[\mathrm{TOS}]$} & 298.15 & $24.33^{1}$ \\
\hline & 318.15 & 24.20 \\
\hline & 328.15 & 24.13 \\
\hline & 338.15 & 24.05 \\
\hline & 348.15 & 23.99 \\
\hline & 358.15 & 23.93 \\
\hline
\end{tabular}


Table 2. Cont.

\begin{tabular}{|c|c|c|}
\hline Ionic liquid & $T / \mathbf{K}$ & $\delta_{2} / \mathrm{MPa}^{0.5}$ \\
\hline \multirow[t]{5}{*}[1,4\mathrm{bmPY}]{$[\mathrm{TOS}]$} & 298.15 & $23.06^{1}$ \\
\hline & 328.15 & 23.24 \\
\hline & 333.15 & 23.27 \\
\hline & 338.15 & 23.29 \\
\hline & 343.15 & 23.33 \\
\hline \multirow[t]{7}{*}[1,4\mathrm{bmPY}]{$\left[\mathrm{NTf}_{2}\right]$} & 298.15 & $20.61^{1}$ \\
\hline & 318.15 & 20.82 \\
\hline & 328.15 & 20.92 \\
\hline & 338.15 & 21.05 \\
\hline & 348.15 & 21.15 \\
\hline & 358.15 & 21.25 \\
\hline & 368.15 & 21.35 \\
\hline \multirow[t]{7}{*}[\mathrm{C}_{6}\mathrm{OCmim}]{$\left[\mathrm{NTf}_{2}\right]$} & 298.15 & $20.26^{1}$ \\
\hline & 318.15 & 20.48 \\
\hline & 328.15 & 20.59 \\
\hline & 338.15 & 20.71 \\
\hline & 348.15 & 20.82 \\
\hline & 358.15 & 20.93 \\
\hline & 368.15 & 21.05 \\
\hline \multirow[t]{7}{*}[(\mathrm{C}_{6}\mathrm{OC})_{2}\mathrm{im}]{$\left[\mathrm{NTf}_{2}\right]$} & 298.15 & $19.60^{1}$ \\
\hline & 318.15 & 19.81 \\
\hline & 328.15 & 19.92 \\
\hline & 338.15 & 20.03 \\
\hline & 348.15 & 20.14 \\
\hline & 358.15 & 20.25 \\
\hline & 368.15 & 20.35 \\
\hline \multirow[t]{8}{*}[\mathrm{Et}_{3}\mathrm{S}]{$\left[\mathrm{NTf}_{2}\right]$} & 298.15 & $21.05^{1}$ \\
\hline & 308.15 & 21.13 \\
\hline & 318.15 & 21.25 \\
\hline & 328.15 & 21.35 \\
\hline & 338.15 & 21.47 \\
\hline & 348.15 & 21.55 \\
\hline & 358.15 & 21.66 \\
\hline & 368.15 & 21.72 \\
\hline \multirow[t]{7}{*}[\mathrm{hmim}]{$\left[\mathrm{NTf}_{2}\right]$} & 298.15 & 20.25 \\
\hline & 308.15 & 20.36 \\
\hline & 313.15 & 20.44 \\
\hline & 328.15 & 20.58 \\
\hline & 333.15 & 20.64 \\
\hline & 338.15 & 20.70 \\
\hline & 348.15 & 20.83 \\
\hline
\end{tabular}


Table 2. Cont.

\begin{tabular}{|c|c|c|}
\hline Ionic liquid & $T / \mathbf{K}$ & $\delta_{2} / \mathrm{MPa}^{0.5}$ \\
\hline \multicolumn{3}{|c|}{ Solubility parameters taken from the literature } \\
\hline \multirow[t]{3}{*}[\mathrm{mmim}]{$\left[\left(\mathrm{CH}_{3}\right)_{2} \mathrm{PO}_{4}\right][21]$} & 312.55 & 26.54 \\
\hline & 332.65 & 25.96 \\
\hline & 352.75 & 25.16 \\
\hline \multirow[t]{3}{*}[\mathrm{emim}]{$\left[\left(\mathrm{C}_{2} \mathrm{H}_{5}\right)_{2} \mathrm{PO}_{4}\right][21]$} & 312.65 & 25.81 \\
\hline & 332.55 & 25.44 \\
\hline & 352.65 & 25.32 \\
\hline$[\mathrm{emim}]\left[\mathrm{NTf}_{2}\right][23]$ & 313.15 & 22.31 \\
\hline$[\mathrm{emim}]\left[\mathrm{NTf}_{2}\right][25]$ & 298.15 & 27.6 \\
\hline$[\mathrm{emim}]\left[\mathrm{BF}_{4}\right][24]$ & 298.15 & 24.4 \\
\hline$[\mathrm{bmim}]\left[\mathrm{BF}_{4}\right][24]$ & 298.15 & 24.3 \\
\hline$[\mathrm{bmim}]\left[\mathrm{BF}_{4}\right][25]$ & 298.15 & 31.6 \\
\hline$[\mathrm{bmim}]\left[\mathrm{NTf}_{2}\right][25]$ & 298.15 & 26.7 \\
\hline$[\mathrm{bmim}]\left[\mathrm{NTf}_{2}\right][26]$ & 298.15 & 25.5 \\
\hline$[\mathrm{bmim}]\left[\mathrm{CF}_{3} \mathrm{SO}_{3}\right][25]$ & 298.15 & 24.9 \\
\hline$[\mathrm{bmim}]\left[\mathrm{CF}_{3} \mathrm{SO}_{3}\right][26]$ & 298.15 & 25.4 \\
\hline \multirow[t]{3}{*}[\mathrm{bmim}]{$\left[\mathrm{PF}_{6}\right][23]$} & 313.15 & 23.2 \\
\hline & 323.15 & 22.62 \\
\hline & 333.15 & 22.05 \\
\hline$[\mathrm{bmim}]\left[\mathrm{PF}_{6}\right][25]$ & 298.15 & 29.8 \\
\hline$[\mathrm{bmim}]\left[\mathrm{PF}_{6}\right][26]$ & 298.15 & 30.2 \\
\hline$\left[\mathrm{bmim}^{2}\left[\mathrm{SbF}_{6}\right][26]\right.$ & 298.15 & 31.5 \\
\hline$[\mathrm{bmmim}]\left[\mathrm{NTf}_{2}\right][26]$ & 298.15 & 24.2 \\
\hline$[\mathrm{hmim}]\left[\mathrm{BF}_{4}\right][24]$ & 298.15 & 23.3 \\
\hline$[\mathrm{hmim}]\left[\mathrm{NTf}_{2}\right][25]$ & 298.15 & 25.6 \\
\hline$[\mathrm{hmim}]\left[\mathrm{PF}_{6}\right][25]$ & 298.15 & 28.6 \\
\hline$[\mathrm{omim}]\left[\mathrm{BF}_{4}\right][24]$ & 298.15 & 22.5 \\
\hline$[\mathrm{omim}]\left[\mathrm{NTf}_{2}\right][25]$ & 298.15 & 25.0 \\
\hline$[\mathrm{omim}]\left[\mathrm{PF}_{6}\right][25]$ & 298.15 & 27.8 \\
\hline$[\mathrm{omim}][\mathrm{Cl}][23]$ & 313.15 & 17.91 \\
\hline \multirow[t]{3}{*}[\mathrm{C}_{16}\mathrm{mim}]{$\left[\mathrm{BF}_{4}\right][22]$} & 323.15 & 19.52 \\
\hline & 333.15 & 19.61 \\
\hline & 343.15 & 19.60 \\
\hline \multirow[t]{3}{*}[\mathrm{OH}-\mathrm{C}_{2}\mathrm{mim}]{$\left[\mathrm{BF}_{4}\right][21]$} & 302.55 & 22.77 \\
\hline & 312.65 & 22.87 \\
\hline & 332.65 & 22.88 \\
\hline \multirow[t]{3}{*}[\mathrm{OH}-\mathrm{C}_{2}\mathrm{mim}]{$\left[\mathrm{PF}_{6}\right][21]$} & 302.65 & 21.84 \\
\hline & 312.55 & 21.93 \\
\hline & 332.45 & 22.45 \\
\hline
\end{tabular}

${ }^{1}$ extrapolated values. 
The values of $\delta_{2}$ calculated using the IGC method are not consistent with those obtained by the intrinsic viscosity method or estimated from the Kamlet-Taft equation. For ionic liquid [bmim] $\left[\mathrm{CF}_{3} \mathrm{SO}_{3}\right]$ the values of $\delta_{2}$ are 22.67, 24.9 [25] and 25.4 [26] obtained by IGC, intrinsic viscosity method or estimated from Kamlet-Taft equation, respectively. For ionic liquid [hmim][NTf $\left.\mathrm{NT}_{2}\right]$ the difference is much greater, values of $\delta_{2}$ are 20.25 and 25.6 [25] for the IGC and intrinsic viscosity methods, respectively. It was found that values of $\delta_{2}$ determined using the IGC method by Mutelet $e t$ al. [21-23] and Foco et al. [24] are also not consistent with those determined by the two methods mentioned above (Table 2). On the other hand, values obtained by different research groups by IGC are coherent as is shown in Figure 1. From Figure 1, it is obvious that for an ionic liquid of general cation formula $[\mathrm{Rmim}]^{+}$, the solubility parameter decreases with an increasing of the alkyl chain R. In the other words, the more aliphatic the cation character, the lower the solubility parameter. The slope of all three lines is similar - it confirms that the data are consistent (except for [emim] $\left[\mathrm{BF}_{4}\right.$ ] ionic liquid).

Figure 1. The solubility parameter versus the number of carbon atoms $n$ in the alkyl chain $\mathrm{R}$ for the ionic liquids based on 1-alkyl-3-methyl-imidazolium cation [Rmim] $]^{+}$obtained by IGC method. ( $\square)[\mathrm{SCN}]^{-} ;(\bullet)\left[\mathrm{BF}_{4}\right]^{-} ;(\Delta)\left[\mathrm{NTf}_{2}\right]^{-}$. The lines are drawn to guide the eye.

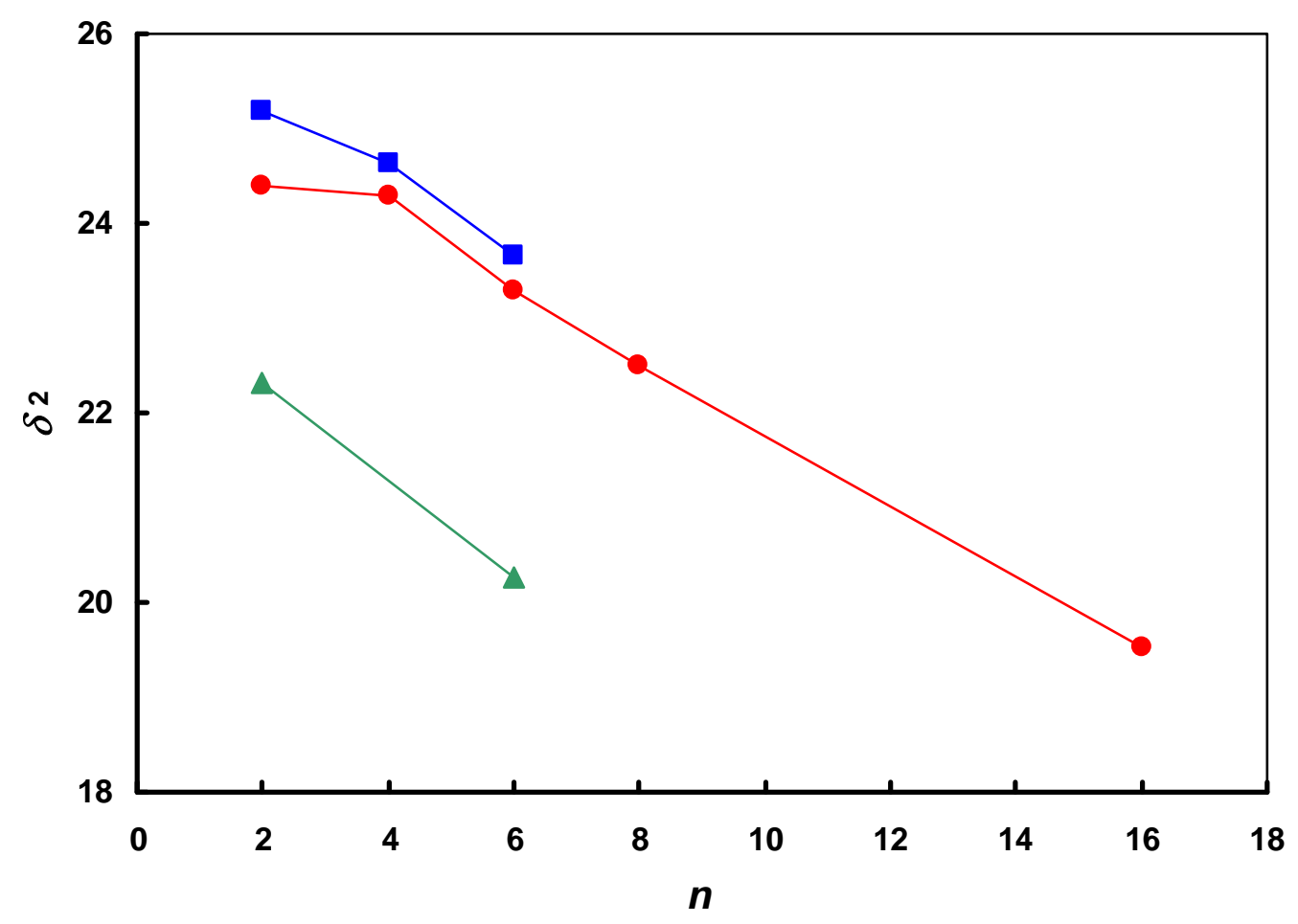

Figure 2 shows the anion influence on the solubility parameter for ionic liquids based on 1-alkyl-3-methyl-imidazolium cations $[\mathrm{Rmim}]^{+}$, 1-butyl-(3 or 4)-methyl-pyridinium [bmPY $]^{+}$and 1-butyl-1-methyl-pyrrolidinium [bmPYR $]^{+}$cations. The solubility parameter increases in the following order: $[\mathrm{Cl}]^{-}<\left[\mathrm{NTf}_{2}\right]^{-}<\left[\mathrm{CF}_{3} \mathrm{SO}_{3}\right]^{-}<\left[\mathrm{OcSO}_{4}\right]^{-}<\left[\mathrm{PF}_{6}\right]^{-}<\left[\mathrm{BF}_{4}\right]^{-}<[\mathrm{TOS}]^{-}<\left[\mathrm{SCN}^{-}<\left[\mathrm{MDEGSO}_{4}\right]^{-}<\right.$ $[\mathrm{TFA}]^{-}$. The highest values of $\delta_{2}$ are for $\left[\mathrm{BF}_{4}\right]^{-},[\mathrm{TOS}]^{-},[\mathrm{SCN}]^{-},\left[\mathrm{MDEGSO}_{4}\right]^{-}$and $[\mathrm{TFA}]^{-}$anions, whilst the lowest value is for the $[\mathrm{Cl}]^{-}$anion. 
Figure 2. Anion influence on the solubility parameter for ionic liquids based on 1-alkyl-3methyl imidazolium cations $[\mathrm{Rmim}]^{+},[\mathrm{bmPY}]^{+}$and $[\mathrm{bmPYR}]^{+}$cations. (घ) $[\mathrm{emim}]^{+} ;(\bullet)$ $[\mathrm{bmim}]^{+} ;(\Delta)[\mathrm{hmim}]^{+} ;(\diamond)[\mathrm{omim}]^{+} ;(\bullet)[1,4 \mathrm{bmPY}]^{+} ;(\circ)[1,3 \mathrm{bmPY}]^{+} ;(\bullet)[\mathrm{bmPYR}]^{+}$.



Figure 3. Influence of cation structure on the solubility parameter for ionic liquids based on $(\square)[\mathrm{SCN}]^{-}$and $(\bullet)\left[\mathrm{CF}_{3} \mathrm{SO}_{3}\right]^{-}$anions. The lines are drawn to guide the eye.

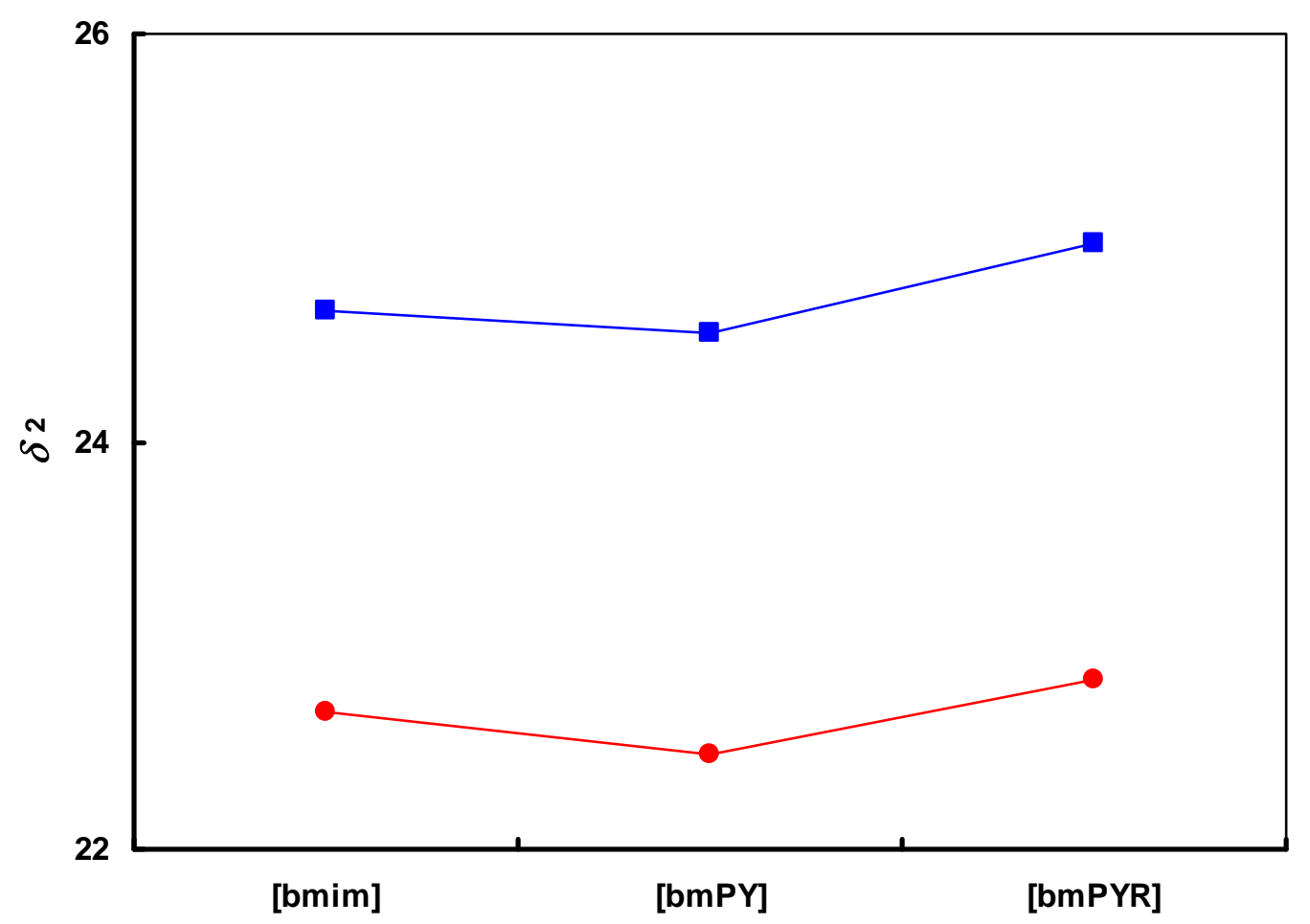


Figure 3 shows influence of the cation structure on the solubility parameter for ionic liquids based on $[\mathrm{SCN}]^{-}$and $\left[\mathrm{CF}_{3} \mathrm{SO}_{3}\right]^{-}$anions. The lowest values of $\delta_{2}$ are for butyl-methyl-pyridinium [bmPY] ${ }^{+}$ cations $\left([1,3 \mathrm{bmPY}]\left[\mathrm{CF}_{3} \mathrm{SO}_{3}\right]\right.$ and $\left.[1,4 \mathrm{bmPY}][\mathrm{SCN}]\right)$.

The influence of the cation on the solubility parameter for the bis(trifluoromethylsulfonyl)-amide based ionic liquids $\left(\left[\mathrm{NTf}_{2}\right]^{-}\right)$is shown in Figure 4 . The solubility parameter increases in the following order: $\left[\left(\mathrm{C}_{6} \mathrm{OC}\right)_{2} \mathrm{im}\right]^{+}<[\mathrm{hmim}]^{+}<\left[\mathrm{C}_{6} \mathrm{OCmim}\right]^{+}<[1,4 \mathrm{bmPY}]^{+}<\left[\mathrm{Et}_{3} \mathrm{~S}\right]^{+}<[\text {emim }]^{+}$. The difference in solubility parameters between $[\mathrm{hmim}]^{+}$and $\left[\mathrm{C}_{6} \mathrm{OCmim}\right]^{+}$cations are very small. It is caused by the similar structure of these two cations. The $\left[\mathrm{C}_{6} \mathrm{OCmim}\right]^{+}$cation has an additional methoxy group (-O$\left.\mathrm{CH}_{2-}\right)$ in the structure, which causes a little augmentation of $\delta_{2}$ value. From this figure, it can be concluded again that the solubility parameter is higher for the ionic liquids with less aliphatic character. It is also presented in Figure 1 and was mentioned previously.

Figure 4. Cation influence on the solubility parameter for ionic liquids based on $\left[\mathrm{NTf}_{2}\right]^{-}$ anion. The line is drawn to guide the eye.

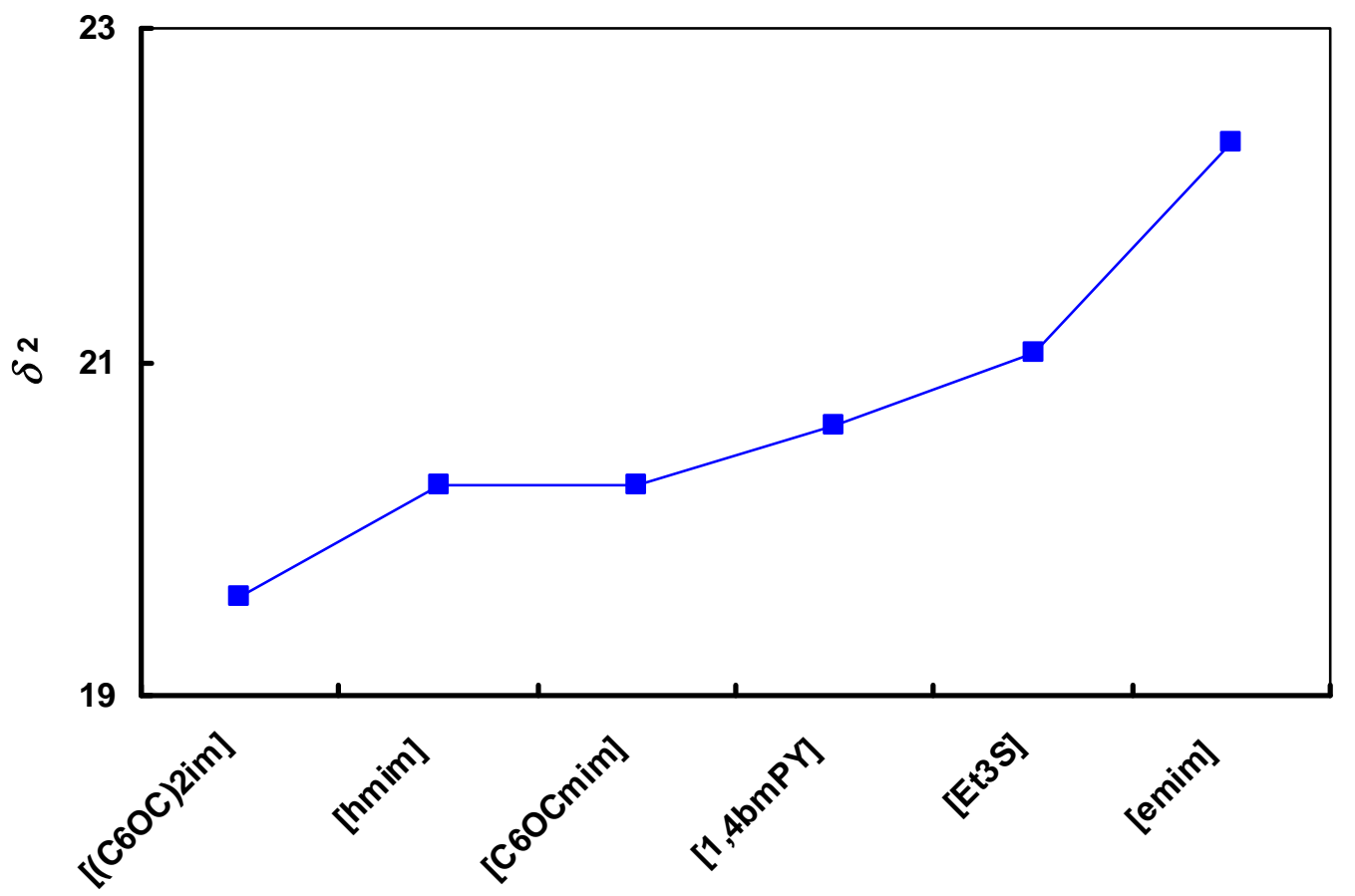

Standard enthalpies of vaporization $\Delta_{\text {vap }} H_{298.15}$ calculated according to equation 8 and molar volumes of ionic liquids necessary in enthalpy calculations are presented in Table 3, and are contrasted the results taken from the literature [25-29]. The larger differences in values of enthalpies of vaporization are for ionic liquids based on the $[\mathrm{SCN}]^{-}$anion. For ionic $[\mathrm{bmim}]\left[\mathrm{CF}_{3} \mathrm{SO}_{3}\right]$ the difference is not so high: 22 and $13 \mathrm{~kJ} \cdot \mathrm{mol}^{-1}$ according to references [27] and [28], respectively. Due to the difference in solubility parameters, values of the enthalpies of vaporization calculated from data from references $[25,26]$ are of course different and larger. For ionic liquid $[1,4 \mathrm{bmPY}]\left[\mathrm{NTf}_{2}\right]$ value of the enthalpy of vaporization is lower by $20 \mathrm{~kJ} \cdot \mathrm{mol}^{-1}$ than for that obtained by Deyko et al. [27]. A very good consistency in results of enthalpies of vaporization is found for [hmim] $\left[\mathrm{NTf}_{2}\right]$ ionic liquid. Result obtained from IGC measurements is only of about 2 and $4 \mathrm{~kJ} \cdot \mathrm{mol}^{-1}$ lower than for that obtained by 
Deyko et al. [27] and Zaitsau et al. [29], whilst the enthalpy of vaporization obtained from the solubility parameter determined by intrinsic viscosity method is much higher at of $216.4 \mathrm{~kJ} \cdot \mathrm{mol}^{-1}$ [25].

Table 3. Molar volumes $V_{m}$ at $T=298.15 \mathrm{~K}$ and standard enthalpies of vaporization $\Delta_{\text {vap }} H_{298.15}$ for investigated ionic liquids.

\begin{tabular}{|c|c|c|c|c|c|c|}
\hline \multirow{2}{*}{$\frac{\text { Ionic liquid }}{[\text { emim][TFA] }}$} & \multirow{2}{*}{$\frac{V_{m} / \mathbf{c m}^{\mathbf{3}} \cdot \mathbf{m o l}^{-1}}{173.7^{1}}$} & \multicolumn{5}{|c|}{$\Delta_{\mathrm{vap}} H_{298.15} / \mathrm{kJ} \cdot \mathrm{mol}^{-1}$} \\
\hline & & $115.9^{7}$ & & & & \\
\hline$[\mathrm{emim}][\mathrm{SCN}]$ & $151.6^{2}$ & $98.6^{7}$ & $151^{8}$ & & & \\
\hline$[\mathrm{bmim}][\mathrm{SCN}]$ & $184.4^{3}$ & $114.5^{7}$ & $148^{8}$ & & & \\
\hline$[\mathrm{hmim}][\mathrm{SCN}]$ & $200.0^{4}$ & $114.3^{7}$ & & & & \\
\hline$[1,4 \mathrm{bmPY}][\mathrm{SCN}]$ & $196.2^{5}$ & 120.5 & & & & \\
\hline [bmPYR][SCN] & $188.8^{5}$ & 120.1 & & & & \\
\hline$[\mathrm{bmim}]\left[\mathrm{CF}_{3} \mathrm{SO}_{3}\right]$ & $222.0^{5}$ & $116.6^{7}$ & $139^{8}$ & $130.2^{9}$ & $140.1^{10}$ & $145.7^{11}$ \\
\hline$[1,3 \mathrm{bmPY}]\left[\mathrm{CF}_{3} \mathrm{SO}_{3}\right]$ & $234.7^{5}$ & $121.0^{7}$ & & & & \\
\hline$[\mathrm{bmPYR}]\left[\mathrm{CF}_{3} \mathrm{SO}_{3}\right]$ & $232.6^{5}$ & $123.7^{7}$ & & & & \\
\hline$[\mathrm{bmim}]\left[\mathrm{MDEGSO}_{4}\right]$ & $284.2^{5}$ & 177.6 & & & & \\
\hline$[\mathrm{bmim}]\left[\mathrm{OcSO}_{4}\right]$ & $327.7^{5}$ & 173.0 & & & & \\
\hline$\left[\mathrm{P}_{1, \mathrm{i} 4, \mathrm{i} 4, \mathrm{i4}}\right][\mathrm{TOS}]$ & $363.4^{6}$ & $217.6^{7}$ & & & & \\
\hline$[1,4 \mathrm{bmPY}]\left[\mathrm{NTf}_{2}\right]$ & $304.8^{5}$ & $132.0^{7}$ & $152^{8}$ & & & \\
\hline$\left[\mathrm{C}_{6} \mathrm{OCmim}\right]\left[\mathrm{NTf}_{2}\right]$ & $349.9^{5}$ & $146.0^{7}$ & & & & \\
\hline$\left[\left(\mathrm{C}_{6} \mathrm{OC}\right)_{2} \mathrm{im}\right]\left[\mathrm{NTf}_{2}\right]$ & $460.2^{5}$ & $179.2^{7}$ & & & & \\
\hline$\left[\mathrm{Et}_{3} \mathrm{~S}\right]\left[\mathrm{NTf}_{2}\right]$ & $273.7^{5}$ & $123.7^{7}$ & & & & \\
\hline$[\mathrm{hmim}]\left[\mathrm{NTf}_{2}\right]$ & $326.4^{5}$ & 136.7 & $139^{8}$ & $141.6^{12}$ & $216.4^{10}$ & \\
\hline \multicolumn{7}{|c|}{1 from reference [30]; } \\
\hline \multicolumn{7}{|c|}{2 from reference $[31]$} \\
\hline \multicolumn{7}{|c|}{3 from reference [32]; } \\
\hline \multicolumn{7}{|c|}{4 from reference [33]; } \\
\hline \multicolumn{7}{|c|}{5 from density measurements pe } \\
\hline \multicolumn{7}{|l|}{ from referen } \\
\hline \multicolumn{7}{|c|}{ calculated from extrapolated values of $\delta_{2}$; } \\
\hline \multicolumn{7}{|c|}{8 from reference [27]; } \\
\hline \multicolumn{7}{|c|}{9 from reference [28]; } \\
\hline \multicolumn{7}{|c|}{${ }^{10}$ calculated from $\delta_{2}$ from reference [25]; } \\
\hline \multicolumn{7}{|c|}{${ }^{11}$ calculated from $\delta_{2}$ from reference [26]; } \\
\hline 12 from refere & e [29] & & & & & \\
\hline
\end{tabular}

\section{Calculation of Solubility Parameters}

\subsection{Experimental Procedure}

The activity coefficients at infinite dilution for all investigated ionic liquids were measured using inverse gas chromatography. Detailed descriptions of materials, apparatus and methods used in each experiment are presented in the certain papers [3-18]. On the basis of the experimental data from the 
activity coefficients at infinite dilution measurements, the Hildebrand's solubility parameters have been calculated using equations presented below.

\subsection{Theoretical Basis}

Retention data were used for the calculation of Hildebrand's solubility parameters, $\delta_{2}$. According to the Flory-Huggins theory the interaction parameter at infinite dilution can be determined using the following expression:

$$
\chi_{12}^{\infty}=\ln \left(\frac{273.15 R}{P_{1}^{*} V_{g} M_{1}}\right)-\frac{P_{1}^{*}\left(B_{11}-V_{1}^{*}\right)}{R T}+\ln \left(\frac{\rho_{1}}{\rho_{2}}\right)-\left(1-\frac{V_{1}^{*}}{V_{2}^{*}}\right)
$$

where $R$ denotes the gas constant, $T$ the temperature, $P_{1}^{*}$ the saturated vapor pressure of the solute at temperature $T, B_{11}$ the second virial coefficient of pure solute, $V_{1}^{*}$ and $V_{2}^{*}$ the molar volume of the solute and solvent respectively, $M_{1}$ the molar mass of solute, $\rho_{1}$ and $\rho_{2}$ density of solute and solvent respectively, $V_{g}$ specific retention volume which is given by:

$$
V_{g}=\frac{273.15 V_{\mathrm{N}}}{T m_{2}}
$$

where $m_{2}$ denotes the mass of the solvent on the column packing and $V_{\mathrm{N}}$ the net retention volume of the solute given by:

$$
V_{\mathrm{N}}=J_{2}^{3} U_{\mathrm{o}}\left(t_{\mathrm{R}}-t_{\mathrm{G}}\right)
$$

where $t_{\mathrm{R}}$ and $t_{\mathrm{G}}$ are the retention times for the solute and an unretained gas, respectively, $U_{\mathrm{o}}$ is the column outlet flow rate, $J_{2}^{3}$ the pressure correction term given by:

$$
J_{2}^{3}=\frac{2}{3} \frac{\left(P_{\mathrm{i}} / P_{\mathrm{o}}\right)^{3}-1}{\left(P_{\mathrm{i}} / P_{\mathrm{o}}\right)^{2}-1}
$$

where $P_{\mathrm{i}}$ and $P_{\mathrm{o}}$ denote the inlet and the outlet pressure, respectively.

The column outlet flow rate corrected for the vapor pressure of water $U_{\mathrm{o}}$ is given by:

$$
U_{o}=U\left(1-\frac{P_{w}}{P_{o}}\right) \frac{T}{T_{f}}
$$

where $T_{f}$ is the temperature of the flow meter, $P_{w}$ is the vapor pressure of water at $T_{f}$ and $U$ is the flow rate measured with the bubble flow meter.

The interaction parameter $\chi_{12}^{\infty}$ may be expressed as a function of $\delta_{1}$ and $\delta_{2}$ which denote the solubility parameters of the solute and of the solvent, respectively by:

$$
\chi_{12}^{\infty}=\frac{V_{1}^{*}\left(\delta_{1}-\delta_{2}\right)^{2}}{R T}
$$

Equation 6 can be rewritten as:

$$
\left(\frac{\delta_{1}^{2}}{R T}-\frac{\chi_{12}^{\infty}}{V_{1}^{*}}\right)=\left(\frac{2 \delta_{2}}{R T}\right) \delta_{1}-\frac{\delta_{2}^{2}}{R T}
$$


The solubility parameters $\delta_{1}$ of the solutes were calculated using following equation:

$$
\delta^{2}=\frac{\Delta_{\text {vap }} H-R T}{v}
$$

where $\Delta_{\mathrm{vap}} H$ denotes enthalpy of vaporization and $v$ the molar volume. Enthalpies of vaporization of solutes were taken from literature [35] and molar volumes were calculated from densities taken from literature [36]. The values of $B_{11}$ were calculated using the McGlashan and Potter [37] equation for alkanes and Tsonopolous [38] equation for the rest of solvents. The vapor pressure values were calculated using equation and constants taken from the literature [36,39,40]. Critical data used to calculate $B_{11}$ were obtained from literature [41,42].

Figure 5. An example of the determination of solubility parameter $\delta_{2}$. Plot of $\frac{\delta_{1}^{2}}{R T}-\frac{\chi_{12}^{\infty}}{V_{1}^{*}}$ versus $\delta_{1}$ according to the equation 7 for ionic liquid $\left[\left(\mathrm{C}_{6} \mathrm{OC}\right)_{2} \mathrm{im}\right]\left[\mathrm{NTf}_{2}\right]$ at $T=368.15 \mathrm{~K}$.

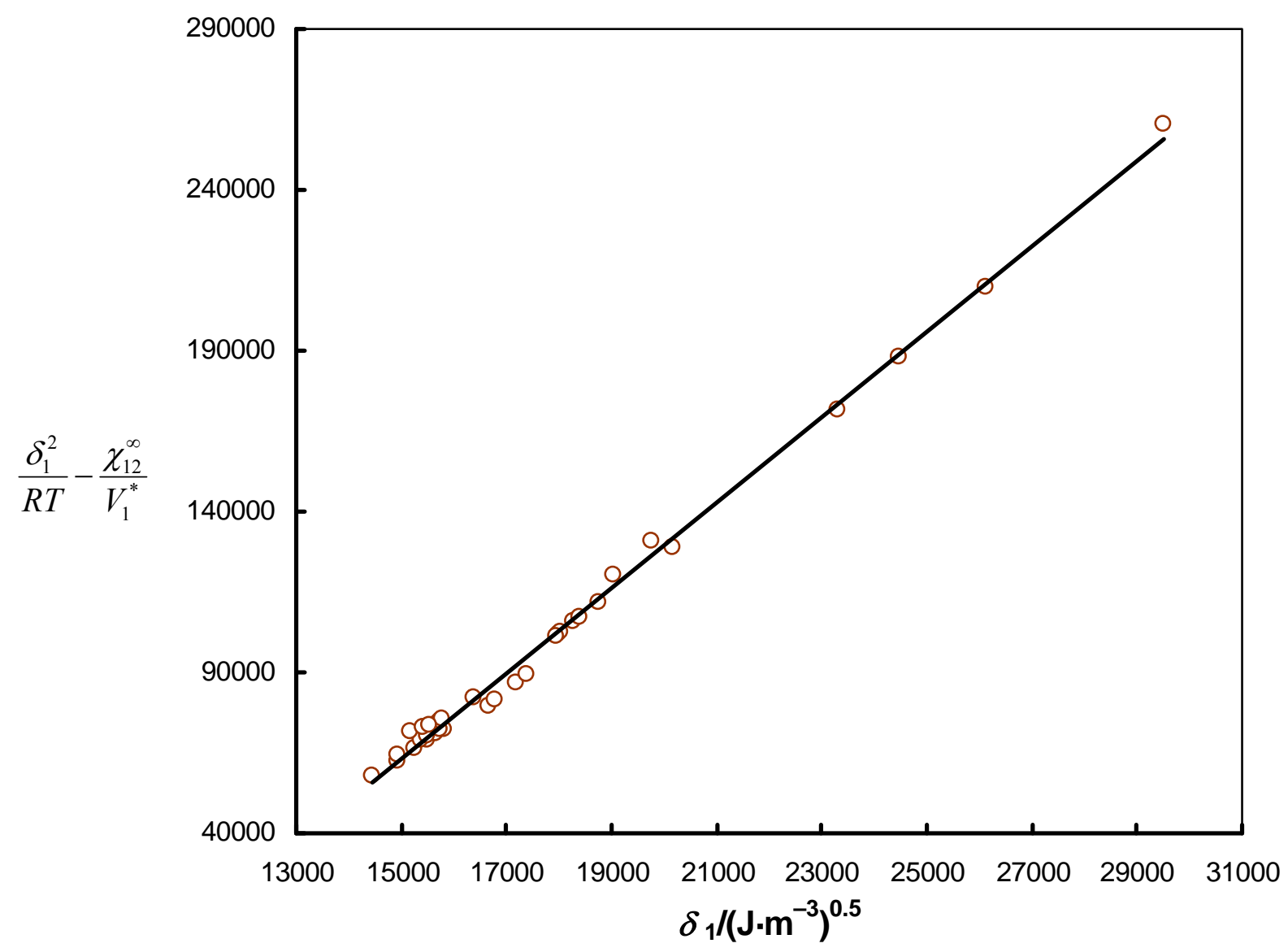

Values of $\chi_{12}^{\infty}$ were determined from equation 1 . If the left side of equation 7 is plotted against $\delta_{1}$, a straight line having a slope of $2 \delta_{2} / R T$ and an intercept of $-\delta_{2}^{2} / R T$ is obtained. The solubility parameter of the solvent $\delta_{2}$ (ionic liquid) can be calculated from the slope and from the intercept of the straight line. The agreement of both $\delta_{2}$ values confirms the applicability of the method to the considered system. An example plot $\frac{\delta_{1}^{2}}{R T}-\frac{\chi_{12}^{\infty}}{V_{1}^{*}}$ versus $\delta_{1}$ is given in Figure 5 for ionic liquid $\left[\left(\mathrm{C}_{6} \mathrm{OC}\right)_{2} \mathrm{im}\right]\left[\mathrm{NTf}_{2}\right]$ at $T=368.15 \mathrm{~K}$. From the slope and interception of straight line the solubility parameter was 
determined, giving results of 20.30 and 20.40 , respectively. Then the average of these values was taken as a final result. The correlation coefficient in this example is 0.996. Hildebrand's solubility parameters of the investigated ionic liquids and the estimated standard enthalpy of vaporization calculated using equation 8 are listed in Tables 2 and 3, respectively.

\section{Conclusions}

Inverse gas chromatography is a reliable method to determine Hildebrand's solubility parameters. Data obtained for 18 ionic liquids are coherent with those obtained by different research group by the same method. From the solubility parameters the standard enthalpies of vaporization can be calculated. Obtained values of enthalpies of vaporization are in acceptable consistency with the data available in literature except for ionic liquids based on thiocyanate anion.

\section{Acknowledgements}

Funding for this research was provided by the Ministry of Science and Higher Education in years 2008-2011 (Grant No. N209 096435). The author would like to thank Urszula Domańska for very helpful discussion and guidance.

\section{Electronic Supporting Information}

Table 1S, interaction parameters, $\chi_{12}^{\infty}$.

\section{References and Notes}

1. Voelkel, A.; Strzemiecka, B.; Adamska, K.; Milczewska, K. Inverse gas chromatography as a source of physiochemical data. J. Chromatogr. A 2009, 1216, 1551-1566.

2. Marciniak. A. Influence of cation and anion structure of the ionic liquid on extraction processes based on activity coefficients at infinite dilution: A review. Fluid Phase Equilib. 2010, doi:10.1016/j.fluid.2009.12.025.

3. Domańska, U.; Marciniak, A. Activity coefficients at infinite dilution measurements for organic solutes and water in the ionic liquid 1-ethyl-3-methylimidazolium trifluoroacetate. J. Phys. Chem. B 2007, 111, 11984-11988.

4. Domańska, U.; Marciniak, A. Measurements of activity coefficients at infinite dilution of aromatic and aliphatic hydrocarbons, alcohols, and water in the new ionic liquid [EMIM][SCN] using GLC. J. Chem. Thermodyn. 2008, 40, 860-866.

5. Domańska, U.; Laskowska, M. Measurements of activity coefficients at infinite dilution of aliphatic and aromatic hydrocarbons, alcohols, thiophene, tetrahydrofuran, MTBE, and water in ionic liquid [BMIM][SCN] using GLC. J. Chem. Thermodyn. 2009, 41, 645-650.

6. Domańska, U.; Marciniak, A.; Królikowska, M.; Arasimowicz, M. Activity coefficients at infinite dilution measurements for organic solutes and water in the ionic liquid 1-hexyl-3methylimidazolium thiocyanate. J. Chem. Eng. Data 2010, doi:10.1021/je900890u.

7. Domańska, U.; Królikowska, M. Measurements of activity coefficients at infinite dilution in solvent mixtures with thiocyanate-based ionic liquids using GLC technique. J. Phys. Chem. B 2010, under review. 
8. Domańska, U.; Marciniak, A. Activity coefficients at infinite dilution measurements for organic solutes and water in the ionic liquid 1-butyl-3-methylimidazolium trifluoromethanesulfonate. $J$. Phys. Chem. B 2008, 112, 11100-11105.

9. Marciniak, A.; Wlazło M. Activity coefficients at infinite dilution for organic solutes and water in the ionic liquid 1-butyl-3-methyl-pyridinium trifluoromethanesulfonate. J. Chem. Eng. Data 2010, doi:10.1021/je1000582.

10. Domańska, U.; Redhi, G.G.; Marciniak, A. Activity coefficients at infinite dilution measurements for organic solutes and water in the ionic liquid 1-butyl-1-methylpyrrolidinium trifluoromethanesulfonate using GLC. Fluid Phase Equilib. 2009, 278, 97-102.

11. Letcher, T.M.; Domańska, U.; Marciniak, M.; Marciniak, A. Activity coefficients at infinite dilution measurements for organic solutes in the ionic liquid 1-butyl-3-methyl-imidazolium 2-(2methoxyethoxy) ethyl sulfate using g.l.c. at $T=(298.15,303.15$, and 308.15) K. J. Chem. Thermodyn. 2005, 37, 587-593.

12. Letcher, T.M.; Marciniak, A.; Marciniak, M.; Domańska, U. Determination of activity coefficients at infinite dilution of solutes in the ionic liquid 1-butyl-3-methylimidazolium octyl sulfate using gas-liquid chromatography at a temperature of $298.15 \mathrm{~K}, 313.15 \mathrm{~K}$, or $328.15 \mathrm{~K}$. J. Chem. Eng. Data 2005, 50, 1294-1298.

13. Domańska, U.; Paduszyński, K. Gas-liquid chromatography measurements of activity coefficients at infinite dilution of various organic solutes and water in tri-iso-butylmethylphosphonium tosylate ionic liquid. J. Chem. Thermodyn. 2010, 42, 707-711.

14. Letcher, T.M.; Ramjugernath, D.; Królikowski, M.; Laskowska, M.; Naidoo, P.; Domańska, U. Activity coefficients at infinite dilution measurements for organic solutes in the ionic liquid $\mathrm{N}$ butyl-4-methylpyridinium tosylate using GLC at $T=(328.15,333.15,338.15$, and 343.15) K. Fluid Phase Equilib. 2009, 276, 31-36.

15. Domańska, U.; Marciniak, A. Activity coefficients at infinite dilution measurements for organic solutes and water in the ionic liquid 4-methyl- $N$-butyl-pyridinium bis(trifluoromethylsulfonyl)imide. J. Chem. Thermodyn. 2009, 41, 1350-1355.

16. Domańska, U.; Marciniak, A. Activity coefficients at infinite dilution measurements for organic solutes and water in the 1-hexyloxymethyl-3-methyl-imidazolium and 1,3-dihexyloxymethylimidazolium bis(trifluoromethylsulfonyl)-imide ionic liquids - The cation influence. Fluid Phase Equilib. 2009, 286, 154-161.

17. Domańska, U.; Marciniak, A. Activity coefficients at infinite dilution measurements for organic solutes and water in the ionic liquid triethylsulphonium bis(trifluoromethylsulfonyl)imide. $J$. Chem. Thermodyn. 2009, 41, 754-758.

18. Letcher, T.M.; Marciniak, A.; Marciniak, M.; Domańska, U. Activity coefficients at infinite dilution measurements for organic solutes in the ionic liquid 1-hexyl-3-methyl-imidazolium bis(trifluoromethylsulfonyl)-imide using g.l.c. at $T=(298.15,313.15$, and 333.15) K. J. Chem. Thermodyn. 2005, 37, 1327-1331.

19. Barton, A.F.M. Solubility parameters. Chem. Rev. 1975, 75, 731-753.

20. Hansen, C.M. Hansen Solubility Parameters: A User's Handbook, 2nd ed.; CRC Press: Boca Raton, FL, USA, 2007. 
21. Revelli, A.-L.; Mutelet, F.; Jaubert, J.-N. Partition coefficients of organic compounds in new imidazolium based ionic liquids using inverse gas chromatography. J. Chromatogr. A 2009, 1216, 4775-4786.

22. Mutelet, F.; Jaubert, J.-N. Measurement of activity coefficients at infinite dilution in 1-hexadecyl3-methylimidazolium tetrafluoroborate ionic liquid. J. Chem. Thermodyn. 2007, 39, 1144-1150.

23. Mutelet, F.; Butet, V.; Jaubert, J.-N. Application of inverse gas chromatography and regular solution theory for characterization of ionic liquids. Ind. Eng. Chem. Res. 2005, 44, 4120-4127.

24. Foco, G.M.; Bottini, S.B.; Quezada, N.; de la Fuente, J.C.; Peters, C.J. Activity coefficients at infinite dilution in 1-alkyl-3-methylimidazolium tetrafluoroborate ionic liquids. J. Chem. Eng. Data 2006, 51, 1088-1091.

25. Lee, S.H.; Lee, S.B. The Hildebrand solubility parameters, cohesive energy densities and internal energies of 1-alkyl-3-methylimidazolium-based room temperature ionic liquids. Chem. Commun. 2005, 3469-3471.

26. Swiderski, K.; McLean, A.; Gordon, C.M.; Vaughan, D.H. Estimates of internal energies of vaporisation of some room temperature ionic liquids. Chem. Commun. 2004, 2178-2179.

27. Deyko, A.; Lovelock, K.R.J.; Corfield, J.-A.; Taylor, A.W.; Gooden, P.N.; Villar-Garcia, I.J.; Licence, P.; Jones, R.G.; Krasovskiy, V.G.; Chernikova, E.A.; Kustov, L.M. Measuring and predicting $\Delta_{\text {vap }} H_{298}$ values of ionic liquids. Phys. Chem. Chem. Phys. 2009, 11, 8544-8555.

28. Sambasivarao, S.V.; Acevedo, O. Development of OPLS-AA force field parameters for 68 unique ionic liquids. J. Chem. Theory Comput. 2009, 5, 1038-1050.

29. Zaitsau, D.H.; Kabo, G.J.; Strechan, A.A.; Paulechka, Y.U.; Tschersich, A.; Verevkin, S.P.; Heintz, A. Experimental vapor pressures of 1-alkyl-3-methylimidazolium bis(trifluoromethylsulfonyl)imides and a correlation scheme for estimation of vaporization enthalpies of ionic liquids. J. Phys. Chem. A 2006, 110, 7303-7306.

30. Rodríguez, H.; Brennecke, J.F. Temperature and composition dependence of the density and viscosity of binary mixtures of water + ionic liquid. J. Chem. Eng. Data 2006, 51, 2145-2155.

31. Domańska, U.; Królikowska, M.; Królikowski, M. Phase behaviour and physico-chemical properties of the binary systems \{1-ethyl-3-methylimidazolium thiocyanate, or 1-ethyl-3methylimidazolium tosylate + water, or + an alcohol\}. Fluid Phase Equilib. 2010, doi:10.1016/j.fluid.2010.01.020.

32. Domańska, U.; Laskowska, M. Temperature and composition dependence of the density and viscosity of binary mixtures of $\{1$-butyl-3-methylimidazolium thiocyanate +1 -alcohols $\} . J$. Chem. Eng. Data 2009, 54, 2113-2119.

33. Domańska, U.; Królikowska, M.; Arasimowicz, M. Phase equilibria of (1-hexyl-3methylimidazolium thiocyanate + water, alcohol, or hydrocarbon) binary systems. J. Chem. Eng. Data 2010, 55, 773-777.

34. Anthony, J.L.; Anderson, J.L.; Maginn, E.J.; Brennecke, J.F. Anion effects on gas solubility in ionic liquids. J. Phys. Chem. B 2005, 109, 6366-6374.

35. Majer, V.; Svoboda, V. Enthalpies of Vaporization of Organic Compounds: A Critical Review and Data Compilation; Blackwell Scientific Publications: Oxford, UK, 1985.

36. DIPPR Project 801 - Full Version; Design Institute for Physical Property Data/AIChE: New York, NY, USA, 2009. 
37. McGlashan, M.L.; Potter, D.J.B. An apparatus for the measurement of the second virial coefficients of vapors; the second virial coefficients of some $n$-alkanes and of some mixtures of $n$ alkanes. Proc. Roy. Soc. 1951, 267, 478-500.

38. Poling, B.E.; Prausnitz, J.M. Properties of Gases and Liquids, 5th ed.; McGraw-Hill Publishing: New York, NY, USA, 2001.

39. Yaws, C.L. Chemical Properties Handbook; McGraw-Hill: New York, NY, USA, $1999 .$.

40. Yaws, C.L.; Narasimhan, P.K.; Gabbula, C. Yaws' Handbook of Antoine Coefficients for Vapor Pressure, 2nd e- ed.; Knovel: New York, NY, USA, 2009.

41. Yaws, C.L. Yaws' Handbook of Thermodynamic and Physical Properties of Chemical Compounds; Knovel: New York, NY, USA, 2003.

42. Dean, J.A. Lange's Handbook of Chemistry, 15th ed.; McGraw-Hill: New York, NY, USA, 1999.

(C) 2010 by the authors; licensee MDPI, Basel, Switzerland. This article is an open-access article distributed under the terms and conditions of the Creative Commons Attribution license (http://creativecommons.org/licenses/by/3.0/). 